\title{
BEHAVIOURAL ANALYSIS IN THE VILLAGE FUND SYSTEM USING THE UTAUT METHOD
}

\author{
Khoirul Fuad $^{1 *}$, Nurrokhmahwati ${ }^{2}$, Retno Tri Handayani ${ }^{3}$ \\ *Corresponding Author \\ ${ }^{1}$ Dept. of Accounting, Faculty of Economics Universitas Islam Sultan Agung, Jalan Raya Kaligawe KM 4, Semarang, \\ Indonesia, khoirulfuad@unissula.ac.id \\ ${ }^{2}$ Dept. of Accounting, Faculty of Economics Universitas Islam Sultan Agung, Jalan Raya Kaligawe KM 4, Semarang, \\ Indonesia, nuy.rw123@gmail.com \\ ${ }^{3}$ Faculty of Economics and Business Uiversitas Muria Kudus, Jalan Lingkar Utara UMK, Gondangmanis, Bae, Kudus, \\ Indonesia retno.tri@umk.ac.id
}

\begin{abstract}
The information system aims to simplify, accelerate, and be responsible. The behavior in the use of technology is an essential part of achieving good village financial management using the Unified Theory of Acceptance and Use of Technology (UTAUT) approach. The population of this research is all village government offices in Tegal Regency. This research is a quantitative study with primary data and a convenience sampling method. This research sample is village apparatus that is directly related to the village fund system (SISKEUDES). Meanwhile, the data analysis of this study uses SPSS software. The test results show that performance expectations negatively affect business expectations, social influences, and conditions that facilitate a positive and significant impact.
\end{abstract}

Keywords: Unified Theory of Acceptance and Use of Technology (UTAUT), village fund system (Siskeudes), behavior

Received

March 29, 2021
Revised

March 30, 2021
Accepted

March 31, 2021
Published

March 31, 2021

\section{INTRODUCTION}

Technology can provide information more quickly and efficiently. The information can be used in all aspects, from education to employment. In the educational aspect, such as elearning provides benefits, educational technology facilities to be used as a medium for uploading learning materials to class assignments (Ardiansyah 2019). The public sector also requires government officials to understand technology to get accurate, fast, and up-to-date information (Mardiana, Tjakraatmadja, and Aprianingsih 2015). Permendagri 20/2018 concerning Village Financial Management, Article 30 issues a regulation amended on village fund management that uses an information system regulated by the Ministry of Home Affairs Number 20 of 2018. The government uses the information system to manage village funds requiring a new system, namely the village fund system (SISKEUDES), which aims to provide transparent and accountable information and facilitate government officials in excellent and orderly government financial management following applicable standards. Therefore, the village government must record its financial transactions as the accountability of village funds using the SISKEUDES application developed by the Financial and Development Supervisory Agency (BPKP).

The successful implementation of this system needs support from village officials as system users, namely by requiring users of each agency's village fund system. The technology of receiving and using information systems remains the main focus in literature 
and becomes a flow to provide an integrated research view in information systems. (Parameswaran, 2015). This study uses the UTAUT model, namely The Unified Theory of Acceptance and Use of Technology, to analyze user behavior from SISKEUDES.

\section{LITERATURE REVIEW}

\section{The Unified Theory of Acceptance and Use of Technology (UTAUT)}

UTAUT is a model developed by (Viswanath 2003), which explains the acceptance of technology that combines eight theories. It includes the theory of reasoned action or TRA, the technology acceptance model or TAM, the motivation model or MM, the theory of planned behavior or TPB. This model combines the technology acceptance model, planned behavior theory or TAM \& TPB, PC utilization or MPCU, innovation diffusion theory or IDT, social cognitive theory, or SCT. Three main factors drive the concept of behavioral interest, which explain an individual's desire to carry out certain activities, including performance expectations, effort expectations, and social influences.

SISKEUDES is a government innovation that requires village governments to implement a village fund system. It is expected that it can give each user confidence, and with this system, it can provide transparency to the community. The basis of this research is to use the Unified Theory of Acceptance and Use of Technology (UTAUT) model in measuring the use of the village fund system (SISKEUDES), which operates four variables, namely performance expectations, business expectations, social influence and facility conditions, without including the moderating variable, namely gender, age, voluntary use and experience (Viswanath 2003).

\section{Hypothesis Development}

\section{The Effect of Performance Expectations on the Behavior of Using SISKEUDES}

The performance expectation construct emphasizes the extent to which village officials' trust or perception in using SISKEUDES can help their work and get performance benefits at work. If the village apparatus has confidence in using the SISKEUDES, this perception can encourage the village apparatus's behavior to use the system in a maximum way.

According to (Venkatesh 2003), the concept of performance expectations is the same as the concept (IDT). Each individual concludes that using new technology will be more valuable than those who did not use the technology. (Kurfali 2017) It proves empirical research states that the variable performance expectation is powerful in influencing other variables as a determinant of interest in using e-government. It similar to (Min 2008) The UTAUT model in the construction of performance expectations is the same as the perceived benefits or TAM, which explains how individuals believe that using the system will help get benefits in job performance. Based on this analysis, the hypothesis is as follows:

H1: Performance expectations have positive and significant effect on the behavior of using the village fund system (SISKEUDES).

\section{The Effect of Business Expectations on the Behavior of Using SISKEUDES}

Business expectations indicate the ease with which the system is used, which it is hoped that users will get used to it and alleviate problems. (Sharma, 2020) Every person can participate in the cognitive trade-off process between efforts to use technology and obtain 
benefits and benefits successfully. If the village fund system (SISKEUDES) is easy to use, then it can encourage usage behavior so that village officials understand and become more proficient in using SISKEUDES. Based on studies (Ramadhanny 2018) Fuad revealed SISKEUDES was developed based on a simple application to fulfil the needs of operational use. It can make it easier for users related to the system, and SISKEUDES is very effective in its application in the government environment.

There have been several previous studies regarding business expectations, such as (Cao 2019) \& (Jewer 2018), who explained that online sales services are trustworthy and easy to use, which get business expectations supported to influence adoption behavior. The analysis above develops the following hypothesis:

H2: Business expectations have positive and significant effect on the behavior of using the village fund system (SISKEUDES).

\section{The Social Effect on SISKEUDES Use Behavior}

Social influence refers to the social stress that some external environment can acquire and influence perceptions through actions such as friends, relatives and others. As individuals to society, such as users, they will be very vulnerable to those around them, such as superiors and relatives, especially those who have significant relationships.

Based on (Venkatesh Robert H. 2003), social influence has three concepts, with their constructs determining the idea that someone active will substantially affect the social environment. The three concepts are the subjective norm (TRA, TAM2). The second concept is the social factor, or MPCU, which determines the internalization of a person's culture and social agreements with others. Finally, the third concept is IDT or image, which means that the perception of using new technology will increase one's social status or get a good idea. (Trybou 2017) Although these concepts have differences, each of these constructs contains an explicit or empirical idea that believing in others can influence one's behavior, resulting from the use of new technology. Therefore, social influence can affect the behavior of SISKEUDES users. With social impact, it is hoped that it can improve village officials' behavior to use the village fund system (SISKEUDES). Based on this analysis, the hypothesis is as follows:

\section{H3: Social Influence has positive and significant effect on the behavior of using the village fund system (SISKEUDES)}

\section{The Effect of Facilitating Conditions on the Behavior of Using SISKEUDES}

The core concept of the construction of this facility condition is related to infrastructure issues that support and implement it easily (Venkatesh 2000). The concept of facilities, conditions for implementing SISKEUDES, the government provides the infrastructure in the form of adequate computers and internet, while technical assistance is in the form of someone who understands using SISKEUDES to help users village officials who experience difficulties or obstacles. The smoothness with the available facilities will support the relationship of village officials to work well.

The condition of the adequately placed facility is critical in system acceptance. SISKEUDES uses user-friendly features so that it can be used easily in operating the village 
fund system. Based on several studies that have been tested, such as (Alwahaishi 2013) on the use of mobile internet on ICT, applications in consumers that show the facility's condition have a significant impact on ICT usage behavior because of the availability of resources or knowledge in internet use. Therefore the fourth hypothesis is:

H4: Facilitating conditions have positive and significant effect of the behavior of using financial fund system (SISKEUDES)

Thus from the description of the hypothesis above, the research model is as follows:

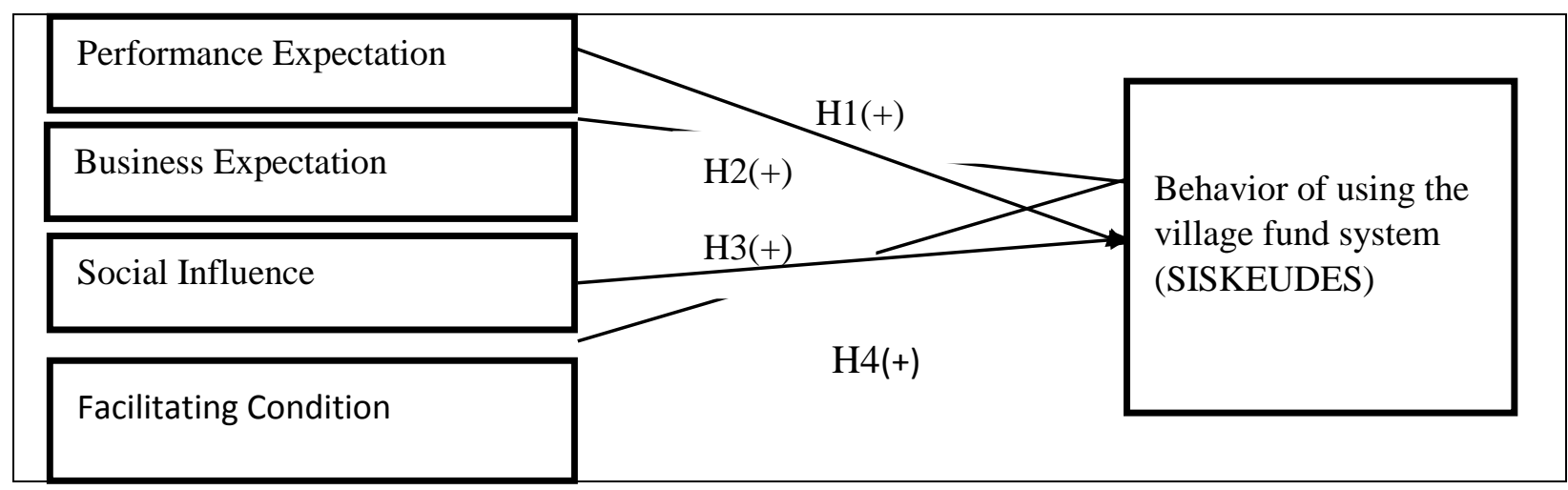

Figure 1. Research Model

\section{Variable and Indicator}

The study's independent variable (Venkatesh and H 2003) is four variables, including performance expectations, business expectations, social influences, and facilitating conditions. Performance expectations are defined at the level of individuals who believe that using the system can improve their job performance, as measured by indicators of perceived usefulness, extrinsic motivation, and job-fit relative advantage.

Business expectations, namely the level of size a person believes that using the system will feel easy or free from the effort with indicators of perceived ease of use, complexity, ease of use. Social influence is the perception of people the importance of the system with subjective norm indicators (Subjective Norm), social factors (Social Factors), image (Image), essential people, society and local government have supported.

Facilitating conditions describe the perception of facilitating conditions to overcome internal and external constraints on user behavior which include self-efficacy, resources, and technology with indicators (Perceived Behavioral Control), having resources (Facilitating conditions), compatibility (Compatibility).

\section{METHOD}

This study used questionnaires directly to respondents, namely village officials in direct contact with the SISKEUDES application at the village government office in Tegal Regency. The study sample was calculated based on the Slovin formula from the entire villages in Tegal Regency, namely 281 villages with a minimum of 74 respondents. After collecting the data, the respondents' data was obtained from 86 respondents. While the analysis technique used to test the data in this study was using SPSS software. 


\section{RESULT}

\section{Descriptive Statistics}

The results of descriptive statistical tests of the variable performance expectations, business expectations and social influences and conditions that facilitate the village fund system are presented in table 1 .

Table 1. Descriptive Statistics

\begin{tabular}{l|l|l|l|l|l}
\hline Variable & N & Min. & Max. & Mean & Std. Dev. \\
\hline Performance Expectations & 86 & 16 & 28 & 24,52 & 2,294 \\
Business Expectations & 86 & 16 & 28 & 22,26 & 2,833 \\
Social Influence & 86 & 16 & 28 & 24,21 & 2,245 \\
Facilitating Conditions & 86 & 14 & 21 & 18,13 & 1,658 \\
The Behavior of Using Siskeudes & 86 & 8 & 14 & 10,77 & 1,485 \\
Valid N (listwise) & 86 & & & & \\
\hline Soun & & & & &
\end{tabular}

Source: Processed primary data, 2021

Based on the table, the results show that the highest mean value is in the performance expectation variable, while the highest standard deviation value lies in the business expectation variable.

\section{Data Quality Test}

The research questionnaire is said to be of quality if it meets the validity and reliability aspects. Here are the results of the data quality test in tables 2 and 3.

Table 2. Validity Test

\begin{tabular}{|c|c|c|c|c|c|}
\hline No & Variable & Statement & r-table & r-count & Valid \\
\hline & Performance Expectations & 1 & \multirow{4}{*}{0,213} & 0,661 & Valid \\
\hline & & 2 & & 0,512 & Valid \\
\hline & & 3 & & 0,607 & Valid \\
\hline & & 4 & & 0,662 & Valid \\
\hline \multirow[t]{4}{*}{2} & Business Expectations & 1 & \multirow{4}{*}{0,213} & 0,842 & Valid \\
\hline & & 2 & & 0,650 & Valid \\
\hline & & 3 & & 0,750 & Valid \\
\hline & & 4 & & 0,568 & Valid \\
\hline \multirow[t]{4}{*}{3} & Social Influence & 1 & \multirow{4}{*}{0,213} & 0,822 & Valid \\
\hline & & 2 & & 0,493 & Valid \\
\hline & & 3 & & 0,593 & Valid \\
\hline & & 4 & & 0,613 & Valid \\
\hline \multirow[t]{3}{*}{4} & Facilitating Condition & 1 & \multirow{3}{*}{0,213} & 0,717 & Valid \\
\hline & & 2 & & 0,342 & Valid \\
\hline & & 3 & & 0,383 & Valid \\
\hline \multirow[t]{2}{*}{5} & The behavior of using SISKEUDES & 1 & \multirow{2}{*}{0,213} & 0,732 & Valid \\
\hline & & 2 & & 0,219 & Valid \\
\hline
\end{tabular}

Source: Processed primary data, 2021 
Based on table 3, it is shown that all statement items used in this study are declared to meet the validity; namely, the calculated $r$-value is more significant than the $r$ table.

Table 3. Reliability Test

\begin{tabular}{clcc}
\hline No & \multicolumn{1}{c}{ Variable } & $\begin{array}{c}\text { Alpha } \\
\text { Coefficient }\end{array}$ & Information \\
\hline 1 & Performance Expectations & 0,864 & Reliable \\
\hline 2 & Business Expectations & 0,889 & Reliable \\
\hline 3 & Social Influence & 0,821 & Reliable \\
\hline 4 & Facilitating Conditions & 0,619 & Reliable \\
\hline 5 & The Behavior of using Siskeudes & 0,655 & Reliable \\
\hline Source: Processed primary data, 2021 & &
\end{tabular}

The data processing results in Table 3 state that all the variables used in this study meet the reliability aspect because the Cronbach alpha value is more significant than 0.6.

\section{Multiple Linear Regression Analysis}

The results of multiple regression testing in this study are presented in the following table and include testing the study's hypothesis.

Table 4. Results of Multiple Linear Regression Analysis

\begin{tabular}{|l|l|l|l|l|l|}
\hline \multicolumn{1}{|c|}{ Information } & \multicolumn{1}{|c|}{$\begin{array}{l}\text { Unstandardized } \\
\text { Coefficient (B) }\end{array}$} & \multicolumn{1}{|c|}{ Sig } & \multicolumn{1}{|c|}{ Hypothesis } & Conclusion \\
\hline $\begin{array}{l}\text { Performance } \\
\text { Expectation }\end{array}$ & $-0,047$ & 0,451 & $\begin{array}{l}\text { Positive } \\
\text { Significant }\end{array}$ & $\begin{array}{l}\text { Negative } \\
\text { Insignificant }\end{array}$ & Rejected \\
\hline $\begin{array}{l}\text { Business } \\
\text { Expectation }\end{array}$ & 0,158 & 0,004 & $\begin{array}{l}\text { Positive } \\
\text { Significant }\end{array}$ & $\begin{array}{l}\text { Positive } \\
\text { Significant }\end{array}$ & Accepted \\
\hline $\begin{array}{l}\text { Social Influence } \\
\text { Socititive }\end{array}$ & 0,225 & 0,034 & $\begin{array}{l}\text { Positive } \\
\text { Significant }\end{array}$ & $\begin{array}{l}\text { Positive } \\
\text { Significant }\end{array}$ & Accepted \\
\hline $\begin{array}{l}\text { Facilitating } \\
\text { Condition }\end{array}$ & 0,017 & $\begin{array}{l}\text { Positive } \\
\text { Significant }\end{array}$ & $\begin{array}{l}\text { Positive } \\
\text { Significant }\end{array}$ & Accepted \\
\hline
\end{tabular}

Source: Processed primary data, 2021

\section{The Effect of Performance Expectation on the Behavior of SISKEUDES Use}

This study's test results show that performance expectations have a negative and insignificant effect on using the village fund system (SISKEUDES). This study's results are not in line with the research (Venkatesh 2003) because most of the previous research was conducted outside the country where there are cultural differences with Indonesia. This study's results can be interpreted that the increase in village officials' performance in Tegal Regency in completing work does not affect individuals to use SISKEUDES. Therefore it can 
be concluded that performance expectations as a determinant of using SISKEUDES are not accepted.

The results of this study are in line with research (Woro et al., 2017), which examines the application of the Bandung Champion system application with the results of performance expectations that do not positively influence the behavioural intentions of SIP Bdg champion users. In research (Verkijika 2018) regarding the adoption of mobile trading applications in Cameroon with performance expectations that are not significant towards behavioural intention to adopt m-commerce. (Novianti, 2010) the results of his research show that performance expectations have no significant effect on interest in using the system or are rejected.

\section{The Effect of Business Expectation on the Behavior of SISKEUDES Use}

Business Expectations in this research can be interpreted as the ease felt by managers in using the information system. This study's test results show that business expectations have a positive and significant influence on using the village fund system (SISKEUDES). It can be interpreted that the greater the business expectation can improve the behaviour of village officials to use SISKEUDES. These results can be interpreted that the SISKEUDES has been appropriately used for fund management and village fund reporting, so application and understanding of SISKEUDES do not require high effort for village officials as users of the village fund system. The easier it is to use SISKEUDES, the village apparatus can understand more quickly and not require more effort to use SISKEUDES.

This study's results are consistent with research by (Venkatesh, 2003), which shows that there is an influence on system users' interest. There are several previous studies whose results are in line, namely (Sair et al. 2018) \& (Warsito 2017), which regarding government employees adopting local e-government transformation with the results of business expectations positively influencing local e-government adoption. Agree with (Muf recallun et al. 2020), who examined the adoption of mobile banking applications in Indonesia, explaining that business expectations are positive and significant on mobile banking adoption behavioural intentions and supported by research (Sharma, 2020).

\section{Social Effect on the Behavior of Using SISKEUDES}

Social Influence is defined as understanding that someone is considered necessary to their surroundings by believing that they must use the system. The test results in this study show that social influences have a positive and significant effect. It is not in line with previous research (Venkatesh, 2003), which in his study, social influence did not affect user behavior. This study proved that village officials were still very dependent on the surrounding environment in using SISKEUDES. Based on research (Cherian, 2013), if individuals believe in their abilities, they can motivate themselves to use the information system.

The social influence on the behavioral context of using SISKEUDES can influence it. In other words, SISKEUDES is believed to be a task that village officials must carry out, and there must be influence or encouragement from the social environment or colleagues as well as from agency leaders. The use of SISKEUDES has not been motivated by the village 
apparatus's desire to use the information system and individual awareness of the professional responsibility to apply because government agencies require it.

This research is not supported by (Andriyanto 2019) \& (Ahmed et al. 2018) to use information technology regarding Abu Dhabi's e-government services. Social influence does not affect the actual users of e-government services. Furthermore, in line with research (Naranjo-Zolotov, 2019) in his research to use and recommend electronic participation, the results show that social influence has no significant effect on the intention to use eparticipation.

\section{The Effect of Facilitating Use on the Behavior of Using SISKEUDES}

Facilitating conditions, specifically the availability of facilities, aim for technical assistance and support from the organization to support SISKEUDES. This study's test results show that facilitating conditions have a positive and significant influence on using the village fund system (SISKEUDES). SISKEUDES can be interpreted as the higher the conditions facilitating the study, the higher the village fund system's behavior. Village officials urgently need adequate facilities, such as computers and a good internet network, to manage village funds and produce village use reports.

This study's results align with research (Jewer 2018) \& (Naranjo-Zolotov, 2019). Conditions that facilitate a positive and significant effect on the intention to use eparticipation - supported by (Warsito 2017) explains that the condition of facilitation is positively related to the intention to adopt organizational structuring. The study results are supported by (Kurfalı et al. 2017) conditions that facilitate user behavior's positive influence. Based on (Rabaa'i 2017), facility conditions positively influence the adoption of e-government services, and on research (Sodiq Onaolapo 2018), which examines the use of smartphones for learning according to facilitating conditions affects smartphone users. On the government side, the use of e-government based on research (Sharma, 2020) is conditions that positively influence the adoption of e-government services. The resources and support services available to their customers will be more motivated to adopt egovernment services.

\section{CONCLUSION}

Based on data analysis and discussion of this study, in can be concluded that the performance expectations are not proven to affect using the village fund system (SISKEUDES). Therefore the first hypothesis is rejected. The behavior of using SISKEUDES is not simple in its use. Meanwhile, business expectations are proven to affect using the village fund system (SISKEUDES). Therefore the second hypothesis is accepted. The higher the business expectations, the village apparatus will not experience problems without requiring more significant effort. Thus the business expectation variable proves the highest considerable value with the other variables.

Furthermore, social influence is proven to affect the behavior of using the village fund system (SISKEUDES). Therefore the third hypothesis is accepted. In each village, there is no compulsion to use the SISKEUDES, but the use of the environmental SISKEUDES impacts 
the desire to know and can use the SISKEUDES. Facilitating conditions are proven to affect using the village fund system (SISKEUDES). Therefore the fourth hypothesis is accepted. It shows that the conditions that facilitate high will help village officials process village fund finances using SISKEUDES..

\section{Implication}

The theoretical implication is expected to contribute to academics who can add insight to further research on UTAUT theory's influence by implementing performance expectations, business expectations, social influences, and conditions that facilitate using SISKEUDES in the village governments.

The government or village officials' practical implications are improving financial management using SISKEUDES in the village government. The application of government SISKEUDES needs to develop a system to make it easier to use and add regular training to SISKEUDES. For the village fund system application developer can pay attention to this research.

\section{Research Limitation}

In this study, the researchers only used a questionnaire tool without using other supporters such as interviews and others. The researcher did not know the respondent's seriousness in filling out the research questionnaire. The questionnaire results' return was less than optimal due to the busyness of the village apparatus along with the covid-19 assistance. The respondents who were processed were 86 respondents because some respondents did not fill out the questionnaire. This study did not include moderating variables such as the initial UTAUT concept.

\section{REFERENCES}

Abbas, Sayyed Khawar, Hafiz Ali Hassan, Jawad Asif, Bilal Ahmed, Fahad Hassan, and Syed Salman Haider. 2018. "Integration of TTF, UTAUT, and ITM for Mobile Banking Adoption." International Journal of Advanced Engineering, Management and Science 4 (5): 375-79. https://doi.org/10.22161/ijaems.4.5.6.

Alshehri, Mohammed, Steve Drew, Thamer Alhussain, and Rayed Alghamdi. 2012. "The Effects of Website Quality on Adoption of E-Government Service: An Empirical Study Applying UTAUT Model Using SEM." ACIS 2012: Proceedings of the 23rd Australasian Conference on Information Systems, no. November.

Alwahaishi, Saleh, and Václav Snášel. 2013. "Consumers 'Acceptance and Use of Information and Communications Technology: A UTAUT and Flow Based Theoretical Model Consumers 'Acceptance and Use of Information and Communications Technology: A UTAUT and Flow Based Theoretical Model," no. May. https://doi.org/10.4067/S0718-27242013000200005.

Andriyanto, Dicky, and Imam Subekti , Zaki Baridwan. 2019. "Jumal Dinamika Akuntansi Dan Bisnis" 6 (2): 151-70.

Andriyanto, Dicky, Zaki Baridwan, and Imam Subekti. 2019. "Anteseden Perilaku Penggunaan E-Budgeting: Kasus Sistem Informasi Keuangan Desa Di Banyuwangi, 
Indonesia." Kasus Sistem Informasi Keuangan Desa Di Banyuwangi, Indonesia 6 (2): 151-70.

Ardiansyah, Ryan, and Dea Diella. 2019. "Implementasi E-Learning Berbasis Assessment For Learning Untuk Meningkatkan Performa Belajar Mahasiswa." BIOSFER : Jurnal Biologi Dan Pendidikan Biologi 3 (1). https://doi.org/10.23969/biosfer.v3i2.1292.

BPKP, Pusdiklatwas. 2016. "BUKU KERJA Aplikasi Sistem Keuangan Desa (SISKEUDES)."

Cao, Qian, and Xiaofei Niu. 2019. "International Journal of Industrial Ergonomics Integrating Context-Awareness and UTAUT to Explain Alipay User Adoption." International Journal of Industrial Ergonomics 69 (October 2017): 9-13. https://doi.org/10.1016/j.ergon.2018.09.004.

Davis, Fred, Richard Bagozzi, and Paul Warshaw. 1989. "User Acceptance of Computer Technology: A Comparison of Two Theoretical Models." Management Science 35 (August): 982-1003. https://doi.org/10.1287/mnsc.35.8.982.

Fishbein dan Ajzen, hal. 216. 1975. "Belief Formation." Encyclopedia of the Sciences of Learning. https://doi.org/10.1007/978-1-4419-1428-6_376.

Haryono, S. 2015. "Petunjuk Praktikum Smart-PLS," no. Ml: 1-13. http://repository.umy.ac.id/bitstream/handle/123456789/2639/Modul Pelatihan PLS.Bag.1.pdf?sequence $=2 \&$ is Allowed $=y$.

Jewer, Jennifer. 2018. "International Journal of Medical Informatics Patients' Intention to Use Online Postings of ED Wait Times : A Modi Fi Ed UTAUT Model” 112 (December 2017): 34-39. https://doi.org/10.1016/j.ijmedinf.2018.01.008.

Kripanont, Napaporn. 2007. "Examining a Technology Acceptance Model of Internet Usage by Academics within Thai Business Schools."

Kurfal1, Murathan, Ali Arifoğlu, Gül Tokdemir, and Yudum Paçin. 2017. "Adoption of EGovernment Services in Turkey." Computers in Human Behavior 66: 168-78. https://doi.org/10.1016/j.chb.2016.09.041.

Lin, Hsiu Fen. 2011. "An Empirical Investigation of Mobile Banking Adoption: The Effect of Innovation Attributes and Knowledge-Based Trust." International Journal of $\begin{array}{llll}\text { Information } & \text { Management } & 31 & \text { (3): }\end{array}$ https://doi.org/10.1016/j.ijinfomgt.2010.07.006.

Mardiana, Siti, Jann H. Tjakraatmadja, and Atik Aprianingsih. 2015. "DeLone-Mclean Information System Success Model Revisited: The Separation of Intention to Use - Use and the Integration of Technology Acceptance Models." International Journal of Economics and Financial Issues 5: 172-82.

Min, Qingfei, Shaobo Ji, and Gang Qu. 2008. "Mobile Commerce User Acceptance Study in China: A Revised UTAUT Model." Tsinghua Science and Technology 13 (3): 257-64. https://doi.org/10.1016/S1007-0214(08)70042-7.

Parameswaran, Srikanth, Rajiv Kishore, and $\mathrm{Pu}$ Li. 2015. "Within-Study Measurement Invariance of the UTAUT Instrument: An Assessment with User Technology Engagement Variables." Information and Management 52 (3): 317-36. https://doi.org/10.1016/j.im.2014.12.007.

Ramadhanny, Ratih Kurnia. 2018. "Inovasi Tata Kelola Keuangan Pemerintah Desa: 
Electronic Village Budgeting ( E-Village Budgeting ) Untuk Menciptakan Good Governance Di Kabupaten Banyuwangi," no. 6.

Sharma, Rashmini, Gurmeet Singh, and Shavneet. 2020. "Modelling Internet Banking Adoption in Fiji: A Developing Country Perspective." International Journal of $\begin{array}{llll}\text { Information } & \text { Management } 53 \quad \text { (June } & \end{array}$ https://doi.org/10.1016/j.ijinfomgt.2020.102116.

sugiyono. 2019. Metode Penellitian Kuantitatif Kualitatid Dan $R \& d$. Edited by sutopo. 1st ed. bandung: alfabeta.

Tarhini, Ali, Kate Hone, and Xiaohui Liu. 2014. "Measuring the Moderating Effect of Gender and Age on E-Learning Acceptance in England: A Structural Equation Modeling Approach for an Extended Technology Acceptance Model." Journal of Educational Computing Research 51 (2): 163-84. https://doi.org/10.2190/EC.51.2.b.

Thompson, Ronald L., Christopher A. Higgins, and Jane M. Howell. 1991. "Personal Computing: Toward a Conceptual Model of Utilization." MIS Quarterly: Management Information Systems 15 (1): 125-42. https://doi.org/10.2307/249443.

Trybou, Jeroen. 2017. "Performance Expectancy, Effort Expectancy and Social Influence as Factors Predicting The Acceptance of (Non-) Fluoroscopy-Guided Positioning For Radiographs, and The Relationship With Leadership." Universiteit Gent Masterproef 1 (1): 2016-17.

Venkatesh, Viswanath, and Fred D. Davis. 2000. "Theoretical Extension of the Technology Acceptance Model: Four Longitudinal Field Studies.” Management Science 46 (2): 186204. https://doi.org/10.1287/mnsc.46.2.186.11926.

Venkatesh, Viswanath, and Robert H. 2003. “Angiogenesis Induced by Mast Cell Secretion in Rat Peritoneal Connective Tissue Is a Process of Three Phases." Microvascular Research 47 (2): 252-69. https://doi.org/10.1006/mvre.1994.1019.

Viswanath Venkatesh Robert H. 2003. "Unusual Formations of Superoxo Heptaoxomolybdates from Peroxo Molybdates." Inorganic Chemistry Communications 67 (3): 95-98. https://doi.org/10.1016/j.inoche.2016.03.015 